\title{
Supervision Practices between School Management Teams and Teachers in Public Secondary Schools in He Fei, China
}

\author{
Wei Yan, Jainabee L.S. Md. Kassim, Mohd Izham HJ Mohd Hamzah, Jamil Bin Ahmad \\ Faculty of Education, National University of Malaysia, Bangi 43600, Malaysia \\ yanweiukm@sina.cn
}

\begin{abstract}
The objective of this case study is to explore the situations of supervision practices between members of school management teams and teachers in public secondary schools in $\mathrm{He}$ Fei, China. The conceptual framework developed on the "Model of Supervisory Practice" by Pajak (1990); meanwhile, combined with Chinese national conditions. 175 managers and 327 teachers participated in the survey randomly, then, the primary data were analyzed by professional statistic research methods. The research results are as following: Firstly, the overall level of supervision practices by managers' viewpoint (mean $=4.129$ ) and teachers' viewpoint $($ mean $=3.586)$ is at high level (mean $=3.41-4.20)$. Secondly, based on the dimension of instructional programs $(\mathrm{t}=$ $2.323, p=0.021$ ), the mean score of younger managers is higher than older managers significantly. Thirdly, among dimensions of communication $(\mathrm{t}=2.140, p=0.033)$, staff development $(\mathrm{t}=2.415$, $p=0.017)$, motivating \& organizing $(\mathrm{t}=2.271, p=0.024)$ and curriculum $(\mathrm{t}=2.407, p=0.017)$, inexperienced teachers have higher mean scores than experienced teachers significantly.

Index Terms - Instructional Supervision, Educational Management, Staff Development, Motivating \& Organizing
\end{abstract}

\section{Introduction}

Supervision is an important aspect of educational management, it could draw together discrete elements of instruction into whole school actions [1], meanwhile, it could reduce the risk of burn-out, enhance work performance and increase job satisfaction [2]. The development of supervision experienced a long and gradual process in it's history which includes six representative stages from late nineteenth century to current. The mentioned stages are supervision as inspection, supervision as social efficiency, democratic supervision, scientific supervision, supervision as leadership and clinical supervision.

In China, the development of supervision practices is behindhand and related problems exist in this area inevitably, therein, three main problems should be realized and emphasized, since this is the beginning which is resolving problems. The first problem is that doesn't have up-to-date and independent system of school supervision. No doubt, there are related elements of supervision in secondary schools, however, these elements are not in an independent system, but discrete in daily life, so that this situation restricts the development of supervision practices, since the focus and implement of supervision practices is misty and unstable. The second problem is that the function of supervision is inspection rather than guidance. It leads to the pattern of educational supervision as measuring, monitoring and even commanding teachers to achieve the scheduled standard, and the emphasis is quantitative, standardized and stylized, so that the role of guiding or mentoring is almost inexistence [3]. The third problem is that teachers' satisfaction is ignored. Over the past many years, Chinese education was merely focused on teachers' employment, appointment, training, assessment and others; however, teachers' pressure, tension, anxiety and discontents were neglected [4].

\section{Research Methodology}

In this study, the sample selection was based on the multistage cluster sampling technique. The sample was selected from each zone and the proportion was made up by the representatives from the total number of school managers and teachers in four zones in He Fei, China. It was stated that the bigger the sample size, the smaller error will likely to happen in the population [5].

Based on the official data of educational department of He Fei, China, the population of managers is 308 and the population of teachers is 3471 . The criterion for sample size was based on the recommendation by Krejcie and Morgan [6]. Thus, there were 175 managers and 346 teachers should be selected in He Fei, China, then, 175 (100\%) managers and 327 $(94.5 \%)$ teachers returned effective questionnaires.

\section{A. Questionnaires}

Based on Pajak's model [7], the questionnaire for this research consisted of 70 items which based on five dimensions that communication, staff development, instructional programs, motivating \& organizing and curriculum. The validity was confirmed by three experts; meanwhile, the reliability was also confirmed by the pilot study.

\section{B. Interpretation of Mean Score}

The 5-point Likert type scale was used in this study which are 1 (Strongly Disagree), 2 (Disagree), 3 (Partially Agree), 4 (Agree) and 5 (Strongly Agree). Then, the levels of mean scores were divided into five ranges [8]. 
TABLE 1: Interpretation of Mean Score

\begin{tabular}{|c|c|}
\hline Mean Score & Interpretation of Mean Score \\
\hline $1.00-1.80$ & Very Low \\
\hline $\mathbf{1 . 8 1}-\mathbf{2 . 6 0}$ & Low \\
\hline $\mathbf{2 . 6 1}-\mathbf{3 . 4 0}$ & Moderate \\
\hline $3.41-4.20$ & High \\
\hline $4.21-5.00$ & Very High \\
\hline
\end{tabular}

Source: Dr. Jamil Bin Ahmad (2012), Faculty of Education, National University of Malaysia.

\section{Results}

\section{A. Levels of Supervision Practices}

Table 2 shows the overall level of supervision practices and five dimensions levels between managers and teachers. From of standpoint of managers, the overall supervision practices $($ mean $=4.129)$ is at high level, then, the dimensions of communication $($ mean $=4.434)$, staff development $($ mean $=$ 4.273 ) and instructional programs (mean $=4.283)$ are at very high level (4.21-5.00), meanwhile, the dimensions of motivating \& organizing (mean $=3.855)$ and curriculum $($ mean $=3.916)$ are at high level, among these dimensions, the dimension of communication is at the highest level. From the standpoint of teachers, the overall level of supervision practices (mean $=3.586)$ and each dimension is at high level (3.41-4.20), therein, the dimension of motivating \& organizing $($ mean $=3.757)$ is at the highest level.

TABLE 2: Levels of Supervision Practices between Managers and Teachers in He Fei, China

\begin{tabular}{|l|l|l|l|l|r|}
\hline $\begin{array}{l}\text { Supervision } \\
\text { Practices }\end{array}$ & M \& T & $\mathrm{N}$ & Mean & SD & $\begin{array}{l}\text { Interpretati } \\
\text { on of Mean }\end{array}$ \\
\hline \multirow{2}{*}{ Com } & Managers & 175 & 4.434 & .526 & Very High \\
\cline { 2 - 6 } & Teachers & 327 & 3.656 & .929 & High \\
\hline \multirow{3}{*}{ SD } & Managers & 175 & 4.273 & .590 & Very High \\
\cline { 2 - 6 } & Teachers & 327 & 3.717 & .935 & High \\
\hline \multirow{2}{*}{ IP } & Managers & 175 & 4.283 & .572 & Very High \\
\cline { 2 - 6 } & Teachers & 327 & 3.708 & .936 & High \\
\hline \multirow{2}{*}{ M \& O } & Managers & 175 & 3.855 & .563 & High \\
\cline { 2 - 6 } & Teachers & 327 & 3.757 & .905 & High \\
\hline \multirow{2}{*}{ Curr } & Managers & 175 & 3.916 & .759 & High \\
\cline { 2 - 6 } & Teachers & 327 & 3.619 & .910 & High \\
\hline \multirow{2}{*}{ Overall } & Managers & 175 & 4.129 & .677 & High \\
\cline { 2 - 6 } & Teachers & 327 & 3.586 & .947 & High \\
\hline
\end{tabular}

Indicators: Com (Communication), SD (Staff Development), IP (Instructional Programs), M \& O (Motivating \& Organizing), Curr (Curriculum)

\section{B. The Differences in Supervision Practices by Demographic Factors}

\section{1) Age between Managers and Teachers}

According to the data of managers, it has a significant difference $(\mathrm{t}=2.323, p=0.021)$ in scores for age group of 40 and less years old $($ mean $=4.392$, s.d. $=0.524)$ and age group of 41 and above years old $($ mean $=4.193$, s.d. $=0.597)$. It shows younger managers have higher level of self-evaluation about instructional programs in He Fei, China. Meanwhile, teachers don't have any significant differences among five dimensions of supervision practices by demographic factor of age.
TABLE 3: T - test Results by Age

\begin{tabular}{|c|c|c|c|c|c|c|}
\hline SP & $\mathrm{M} \& \mathrm{~T}$ & Age & Mean & $\mathrm{SD}$ & t-value & $p$ \\
\hline \multirow[t]{4}{*}{ Com } & \multirow[t]{2}{*}{ Managers } & 40 and less & 4.514 & .478 & 1.839 & .068 \\
\hline & & 41 and above & 4.368 & .557 & & \\
\hline & \multirow[t]{2}{*}{ Teachers } & 40 and less & 3.703 & .932 & 1.547 & .123 \\
\hline & & 41 and above & 3.523 & .910 & & \\
\hline \multirow[t]{4}{*}{ SD } & \multirow[t]{2}{*}{ Managers } & 40 and less & 4.369 & .548 & 1.961 & .051 \\
\hline & & 41 and above & 4.195 & 614 & & \\
\hline & \multirow[t]{2}{*}{ Teachers } & 40 and less & 3.757 & .915 & 1.301 & .194 \\
\hline & & 41 and above & 3.605 & .986 & & \\
\hline \multirow[t]{4}{*}{ IP } & \multirow[t]{2}{*}{ Managers } & 40 and less & 4.392 & .524 & 2.323 & $.021 *$ \\
\hline & & 41 and above & 4.193 & .597 & & \\
\hline & \multirow[t]{2}{*}{ Teachers } & 40 and less & 3.764 & .916 & 1.801 & .073 \\
\hline & & 41 and above & 3.552 & 979 & & \\
\hline \multirow[t]{4}{*}{$\mathrm{M} \& \mathrm{O}$} & \multirow[t]{2}{*}{ Managers } & 40 and less & 3.907 & .564 & 1.124 & .263 \\
\hline & & 41 and above & 3.811 & .562 & & \\
\hline & \multirow[t]{2}{*}{ Teachers } & 40 and less & 3.811 & .853 & 1.671 & .097 \\
\hline & & 41 and above & 3.605 & 1.026 & & \\
\hline \multirow[t]{4}{*}{ Curr } & \multirow[t]{2}{*}{ Managers } & 40 and less & 3.996 & .804 & 1.270 & .206 \\
\hline & & 41 and above & 3.850 & .717 & & \\
\hline & \multirow[t]{2}{*}{ Teachers } & 40 and less & 3.674 & .862 & 1.837 & .067 \\
\hline & & 41 and above & 3.465 & 1.023 & & \\
\hline
\end{tabular}

Indicators: Com (Communication), SD (Staff Development), IP (Instructional Programs), M \& O (Motivating \& Organizing), Curr (Curriculum)

\section{2) Years of Experience in the Role between Managers and Teachers}

Two groups' managers don't have significant differences among five dimensions of supervision practices by demographic factor which is years of experience in the role. Meanwhile, based on the teachers' data, among dimensions of communication $(\mathrm{t}=2.140, p=0.033)$, staff development $(\mathrm{t}=$ $2.415, p=0.017)$, motivating $\&$ organizing $(\mathrm{t}=2.271, p=$ $0.024)$ and curriculum $(\mathrm{t}=2.407, p=0.017)$, teachers whose years of experience is 0 to 6 years have higher mean scores of supervision practices than teachers who have 7 and above years' experience.

TABLE 4: $\mathrm{T}$ - test Results by Years of Experience in the Role

\begin{tabular}{|c|c|c|c|c|c|c|}
\hline SP & $\mathrm{M} \& \mathrm{~T}$ & Age & Mean & SD & $\mathrm{t}$-value & $p$ \\
\hline \multirow[t]{4}{*}{ Com } & \multirow[t]{2}{*}{ Managers } & 0 to 6 years & 4.474 & .571 & .294 & .769 \\
\hline & & 7 and above & 4.431 & .524 & & \\
\hline & \multirow[t]{2}{*}{ Teachers } & 0 to 6 years & 3.833 & .841 & 2.140 & $.033 *$ \\
\hline & & 7 and above & 3.589 & .953 & & \\
\hline \multirow[t]{4}{*}{ SD } & \multirow[t]{2}{*}{ Managers } & 0 to 6 years & 4.456 & .521 & 1.209 & .228 \\
\hline & & 7 and above & 4.258 & .594 & & \\
\hline & \multirow[t]{2}{*}{ Teachers } & 0 to 6 years & 3.906 & .831 & 2.415 & $.017 *$ \\
\hline & & 7 and above & 3.646 & .964 & & \\
\hline \multirow[t]{4}{*}{ IP } & \multirow[t]{2}{*}{ Managers } & 0 to 6 years & 4.418 & .541 & .922 & .358 \\
\hline & & 7 and above & 4.271 & .575 & & \\
\hline & \multirow[t]{2}{*}{ Teachers } & 0 to 6 years & 3.822 & .875 & 1.362 & .174 \\
\hline & & 7 and above & 3.665 & .957 & & \\
\hline \multirow[t]{4}{*}{$\mathrm{M} \& \mathrm{O}$} & \multirow[t]{2}{*}{ Managers } & 0 to 6 years & 3.967 & .512 & .776 & .439 \\
\hline & & 7 and above & 3.845 & .568 & & \\
\hline & \multirow[t]{2}{*}{ Teachers } & 0 to 6 years & 3.928 & .799 & 2.271 & $.024 *$ \\
\hline & & 7 and above & 3.692 & .935 & & \\
\hline \multirow[t]{4}{*}{ Curr } & \multirow[t]{2}{*}{ Managers } & 0 to 6 years & 4.050 & .762 & .687 & .493 \\
\hline & & 7 and above & 3.904 & .760 & & \\
\hline & \multirow[t]{2}{*}{ Teachers } & 0 to 6 years & 3.800 & .793 & 2.407 & $.017 *$ \\
\hline & & 7 and above & 3.551 & .943 & & \\
\hline
\end{tabular}

Indicators: Com (Communication), SD (Staff Development), IP (Instructional Programs), M \& O (Motivating \& Organizing), Curr (Curriculum) 


\section{Discussion}

\section{A. Levels of Supervision Practices}

Based on the data of analysis, this study could identify that the levels of supervision practices are optimistic by and large, even so, the related dimensions should be improved for better school management and school outcomes, since the focus of research is not only findings and encouragement, but also solving problems, then, achieving the advancements.

From of standpoint of managers, they consider that the dimension of communication has the strongest level. It is a reasonable finding, since communication is a necessary approach to exchange ideas and understand each other in human society; moreover, no doubt that it's a very important ability to any outstanding managers, since management is an art which is coordinating and communicating people. This study suggests that the dominant position of strongest dimension should be kept with related skills which are i) simple and clear message, ii) restrain emotions, iii) listen closely and iv) provide enough feedback[9]. In addition, managers should be diligent in self-examination, since this is not only the traditional virtue, but also the job demand.

In addition, managers consider the dimension of motivating and organizing is the weakest point in the supervision practices. It means managers should pay more attention to motivating teachers and school organizing in managers' own opinion. Meanwhile, it is possible that managers met more difficulties in this dimension than other dimensions in daily working. Based on the viewpoint of Glickman \& Gordon \& Ross-Gordon [1], this study suggests that continuous behaviours and collaboration behaviours which are between managers and teachers need to be implemented for better improvement of motivating \& organizing.

From of standpoint of teachers, an interesting phenomenon was identified by this study which is among of five dimensions of supervision practices, teachers have inverse standpoint with managers that the strongest dimension is motivating and organizing. It is possible that managers tried their best to resolve the difficulties about this dimension for teachers, since managers consider this dimension is at the lowest level, then, it lead to teachers feel better than managers. This study suggests that managers and teachers should better exchange their opinions deeply about all of dimensions of supervision practices, since it is necessary for improving the levels of supervision practices and benefit to managers and teachers' daily working, even good at the whole school efficiency.

In addition, although teachers' opinion of each dimension is at high level, the dimension of curriculum is at the lowest level. As everyone knows, Chinese social pressure is very heavy, so that the scores of curriculum is priority among priorities in school daily working, since it has closed relationship with school reputation and students' future. In other word, the pressure of curriculum is too heavy, then, the needs of curriculum are difficult to satisfy. Therefore, school mangers and educational departments should support more allsided and thoughtful guidance and services to teachers for their common focus. Moss [10] proposed that school managers should guide teachers to better understand the school's rules of curriculum, suitable curriculum plans, useful material, and amiable tone and attitude. Based on Chinese current situation, this study suggests that try to best to decrease teachers' pressure, as well as students, since going too far is as bad as not going far enough. In addition, although the factor of scores has special status in Chinese society, this study hopes to remind that the focus the education is not only the scores of curriculum, but also students' growth, as well as teachers' growth.

\section{B. Age between Managers and Teachers}

In $\mathrm{He} \mathrm{Fei}$, other four dimensions don't have significant difference based on age, except the dimension of instructional programs which younger managers have higher level than older managers. This study suggests that older managers should better pay more attention to the dimension of instructional programs for better supervision practices. In addition, although this is self-evaluation by managers, the results should be trusted, since managers have qualified moral and correct attitude to evaluate them.

At the same time, although two age group teachers' mean scores don't have significant differences, younger teacher have slight higher mean scores, thus, this study could deduce that younger teachers obtained more and better guidance of supervision practices from managers.

\section{Years of Experience in the Role between Managers and Teachers}

School managers don't have significant differences about five dimensions of supervision practices, it could be considered that the demographic factor of years of experience in the role could not influence managers' attitude about levels of supervision practices significantly.

Meanwhile, teachers' data shows different situation from managers' data. Based on the research finding, this study could deduce that inexperienced teachers obtained more guidance and help from school managers. This is positive finding, since inexperienced teachers need more guidance and help for better daily work; in addition, it is not only benefit to teachers' growth, but also benefit to students' growth and the whole school productivities. However, this study considers it is necessary to remind $\mathrm{He}$ Fei educational departments and secondary schools that managers need pay more attention to experienced teachers, although they are experienced, they face changeable situation about their working and encounter new challenges endlessly.

\section{Conclusion}

Managers and teachers are the two sides of educational supervision. On the one hand, the key point of educational supervision practices is the role of managers, since they are executors of supervision practices. On the other hand, teachers are the target of supervision practices. Thus, there is no 
shirking the responsibility to cooperate together by both managers and teachers.

This study proposes three suggestions to school managers and teachers for better supervision practices in the future. Firstly, managers should provide guidance to teachers based on teachers' different characteristics respectively, since each teacher has different profiles, skills, interests and experiences. No doubt, these different factors certainly will lead to teachers are difficult to be managed by a single managerial model. Thus, managers have duty to identify teachers' different complex characteristics clearly, then, treat different teachers with different corresponding managerial activities. Secondly, school managers have responsibilities to supply necessary channels of feedback to teachers, in order to realize the situations of supervision practices and teachers' satisfaction during the process of daily working. Meanwhile, teachers have also responsibilities that propose their real opinions in time. It seems to this study, the system of feedback should be set up formally, since the activities are easy to be changed or interrupted, if related managers are changed or other negative factors appeared. Thirdly, managers and teachers should respect and trust each other, as well as keep their promise. It is necessary to effective supervision practices, then, set up a positive school atmosphere and friendly relationships between managers and teachers. As a researcher in the area of educational management, this study wants to emphasize that the essence of management is manage interpersonal relationships. Thus, school managers have duty to understand the implication of respect, trust and promise, then, implement their managerial working with these key factors, meanwhile, managers should share the correct ideas and important experiences with teachers, in order to teachers could treat other people with this good moral. Moreover, school managers and teachers' behaviours are the best vivid teaching activities; their positive and virtuous behaviours could exert a subtle influence on students' growth. It seems to this study, this is important too much than teaching the content of books.

\section{Reference}

[1] Glickman, C.D. \& Gordon, S.P. \& Ross-Gordon, J.M., 2007. Supervision and Instructional Leadership: A Developmental Approach. Reilly, E. $7^{\text {th }}$ ed. USA: Pearson Education.

[2] Rico.2010. Supervision. Resilient Individuals, Communities \& Organizations Training, Processes \& Strategies. PO Box 1328, WODEN ACT 2606.

http://www.rico.com.au/training/life_skills/supervision.htm (20 August 2012).

[3] Zhu, Q., Yang, X. and Cai, W.Q.,2006. Issues and Analysis: Contemporary Educational Supervision Research. Tian Jin: Educational Press.

[4] Zhou, M. \& Shi, D.W. 2009. Investigation of Teachers' Psychology Health in Key Secondary Schools. Educational Theory and Practice. 31.

[5] Creswell, J.W. 2005. Educational Research. Planning, Conducting, and Evaluating Quatitative and Qualitative Research. In OTED 1083 \& OTED 1085 Qualitative Research Methods Readings. Sydney: Pearson Education Australia.

[6] Krejcie, R. V. \& Morgan, D. W. 1970. Determining Sample Size for Research Activities. Educational and Psychological Measurement. 30, 607-610.

[7] Pajak, E. 1990. Identification of Dimensions of Supervisory Practice in Education: Reviewing the Literature. Document ED 320285.

[8] Jamil, H \& Razak, N.A. \& Raju, R. \& Rashid, A.M. 2010. Universiti Sains Malaysia. 85-102.

[9] Murphy, P. 2007. How to Improve Communication with Interpersonal Insights (online). http://ezinearticles.com/?How-To-Improve-Communication-WithInterpersonal-Insights\&id=651153 (18 August 2012).

[10] Moss, L., 2012. How to Plan for Effective Teaching \& Learning. Demand Media. (online)http://www.ehow.com/how_7578272_planeffective-teaching-learning.html (16 August 2012) 